\title{
Wnt expression and canonical Wnt signaling in human bone marrow B lymphopoiesis
}

\author{
Guri Døsen, Ellen Tenstad, Marit Kveine Nygren, Heidi Stubberud, \\ Steinar Funderud and Edith Rian*
}

\begin{abstract}
Address: Department of Immunology, Institute for Cancer Research, Rikshospitalet-Radiumhospitalet Medical Center, Medical Faculty, University of Oslo, Norway

Email: Guri Døsen - guri.dosen@rr-research.no; Ellen Tenstad - et@hive.no; Marit Kveine Nygren - marit.nygren@rr-research.no;

Heidi Stubberud - heidi.stubberud@rr-research.no; Steinar Funderud - steinar.funderud@ @rr-research.no; Edith Rian* - edith.rian@rr-research.no

* Corresponding author
\end{abstract}

Published: 29 June 2006

BMC Immunology 2006, 7:13 doi:10.1186/147/-2172-7-13
Received: 09 November 2005

Accepted: 29 June 2006

This article is available from: http://www.biomedcentral.com/147/-2/72/7//3

(C) 2006 Døsen et al; licensee BioMed Central Ltd.

This is an Open Access article distributed under the terms of the Creative Commons Attribution License (http://creativecommons.org/licenses/by/2.0), which permits unrestricted use, distribution, and reproduction in any medium, provided the original work is properly cited.

\begin{abstract}
Background: The early B lymphopoiesis in mammals is regulated through close interactions with stromal cells and components of the intracellular matrix in the bone marrow (BM) microenvironment. Although B lymphopoiesis has been studied for decades, the factors that are implicated in this process, both autocrine and paracrine, are inadequately explored. Wnt signaling is known to be involved in embryonic development and growth regulation of tissues and cancer. Wnt molecules are produced in the BM, and we here ask whether canonical Wnt signaling has a role in regulating human BM B lymphopoiesis.
\end{abstract}

Results: Examination of the mRNA expression pattern of Wnt ligands, Fzd receptors and Wnt antagonists revealed that BM B progenitor cells and stromal cells express a set of ligands and receptors available for induction of Wnt signaling as well as antagonists for fine tuning of this signaling. Furthermore, different $B$ progenitor maturation stages showed differential expression of Wnt receptors and co-receptors, $\beta$-catenin, plakoglobin, LEF-I and TCF-4 mRNAs, suggesting canonical Wnt signaling as a regulator of early $B$ lymphopoiesis. Exogenous Wnt $3 \mathrm{~A}$ induced stabilization and nuclear accumulation of $\beta$-catenin in primary lineage restricted $B$ progenitor cells. Also, Wnt3A inhibited $\mathrm{B}$ lymphopoiesis of $\mathrm{CDI} 33^{+} \mathrm{CDIO}$ - hematopoietic progenitor cells and $\mathrm{CDIO} 0^{+} \mathrm{B}$ progenitor cells in coculture assays using a supportive layer of stromal cells. This effect was blocked by the Wnt antagonists sFRPI or Dkkl. Examination of early events in the coculture showed that Wnt3A inhibits cell division of $B$ progenitor cells.

Conclusion: These results indicate that canonical Wnt signaling is involved in human BM B lymphopoiesis where it acts as a negative regulator of cell proliferation in a direct or stroma dependent manner.

\section{Background}

In mammals, the early antigen independent phase of $\mathrm{B}$ lymphopoiesis takes place in the intersinusoidal spaces in the bone marrow (BM). Here, the $\mathrm{B}$ cell progeny mature from hematopoietic stem cells (HSC) via early lymphoid progenitors (ELP, comprising common lymphoid progen- 
itors and early B), pro-B, pre-B and immature B developmental stages characterized by successive steps in the rearrangement of immunoglobulin genes and consecutive expression of cellular markers [1-3]. Using immunohistochemical doublestaining we have revealed earlier that all developmental stages of the B cell lineage in human BM tissue are in close contact with slender $\mathrm{CD} 10^{+}$stromal cells or their extensions [4]. This finding correlates with the consensus that $\mathrm{B}$ lymphopoiesis is tightly regulated by signals provided by mesenchymal stromal cells and components of the intracellular matrix in the $\mathrm{BM}$ microenvironment in vivo [4-6]. However, the elements of this signaling are yet inadequately identified; stromal factors like IL 7, Flt3 ligand [7], IL-3 [8,9] and SDF1 $[10,11]$ are essential, but not sufficient for BM B lymphopoiesis [2]. Clearly, there is a need for further characterization of both the stromal phenotype as well as the autocrine and paracrine factors that participate in the regulation of $\mathrm{BM} \mathrm{B}$ lympopoiesis.

Wnt proteins belong to a large and highly conserved family of secreted, cystein-rich glycoprotein signaling molecules, consisting of 19 members. They are likely to act locally because of their limited solubility [12] and tendency to associate with the cell surface extracellular matrix [13]. Signaling is initiated by Wnt proteins binding to receptors of the Frizzled family (Fzd) on the cell surface. This binding is promiscuous and the ligand/receptor specificities are not yet properly determined. Depending on particular Wnt/Fzd combinations, at least three signaling cascades may be activated. Most studied is the canonical Wnt pathway, which is activated by members of the Wnt 1 class (such as Wnt1, Wnt2, Wnt3 and Wnt8) [14]. A key regulatory molecule in this pathway is $\beta$-catenin, which in the absence of a Wnt signal is kept low through continuous phosporylation by glycogen synthase kinase- $3 \beta$ (GSK$3 \beta)$, resulting in a subsequent proteasome dependent destruction of $\beta$-catenin. Binding of Wnt ligands to Fzd receptors and coreceptors LRP5/6, leads to inactivation of GSK3 $\beta$ and thereby accumulation of nonphosphorylated $\beta$-catenin, which enter the nucleus. Here, $\beta$-catenin acts as a coactivator of members of the lymphoid enhancer factor-1 (LEF-1)/T-cell factor (TCF) family of transcription factors to stimulate transcription of Wnt target genes [15]. Activation of Wnt signaling can be inhibited by soluble antagonists, including the Dickkopf (Dkk) family and the soluble Fzd related proteins (sFRP) [16].

Recently, Wnt proteins have drawn attention as a set of factors operating in embryonic development, growth regulation of adult tissues and cancer formation [15,17-20]. Moreover, Wnt signaling plays a central role in the communication between HSC and stromal cells [21] as well as in several other stem cell niches $[22,23]$. Several observations have established direct roles for Wnt signaling in the maturation process where hematopoietic stem cells lose their pluripotency and commit to specific lineages [2426]. LEF-1 and Fzd9 knockout mice show defect B lymphopoiesis $[24,27]$ and Wnt signaling seems to be involved in development of leukemia [28-30] and malignant myeloma [31]. Moreover, in murine B lymphopoiesis this signaling pathway has a stimulatory effect on proB cells from fetal liver [24]. As early B lymphopoiesis in mice and humans to a certain extent shows distinct factor dependency [32], and since fetal and adult lymphopoiesis takes place in different maturation niches, the aim of the present study was to investigate Wnt signaling in human BM B lymphopoiesis in more detail. We have examined which Wnt signaling pathway molecules that are expressed in B progenitor cells and stromal cells from human BM, and analyzed the regulated expression of several Wnt receptors (Fzd and LRP), $\beta$-catenin and plakoglobin as well as the central transcription factors LEF-1 and TCF-4 during the early B lymphopoiesis. Furthermore, we have investigated the effect of recombinant Wnt3A on progenitor B cells. We found that Wnt3A induced $\beta$-catenin stabilization and inhibited in vitro $\mathrm{B}$ lymphopoiesis in a coculture with stromal cells by suppression of initial cell proliferation. Thus, canonical Wnt signaling may be involved in human BM B lymphopoiesis.

\section{Results \\ A distinct set of Wnt ligands, Fzd receptors and Wnt antagonists is expressed in B progenitor cells and stromal cells from human $B M$}

Previous work has demonstrated expression of Wnt5A, Wnt2B and Wnt10B in pooled human BM populations [26]. However, the expression pattern of Wnt ligands, Fzd receptors and Wnt antagonists in human $B$ lineage cells has not been explored. In the absence of available antibodies to detect these large families of proteins, we performed conventional RT-PCR on RNA isolated from FACS sorted B progenitor cells (CD10+IgM-CD45 ${ }^{+}$) pooled from three different donors, using primers designed specifically to detect mRNA expression of all known Wnt ligands and Fzd receptors as well as the Wnt antagonists Dkk1, Dkk4, sFRP1-4 and WIF1 (fig. 1 and table 1). In B progenitor cells, Wnt 2B, 5B, 8A, 10A and 16 mRNAs were readily detected. Interestingly, the Wnt 16 PCR product had two bands of $520 \mathrm{bp}$ and $233 \mathrm{bp}$, respectively (fig. 1). The 520 bp band represents the full-length form and the $233 \mathrm{bp}$ band represents a possible splice variant lacking exon 3, potentially giving rise to a truncated Wnt 16 form. In addition, expression of several other Wnt mRNAs was detectable, however, less readily (table 1). The Fzd receptors showed on average much higher mRNA expression levels than the Wnts, where Fzd2, 3, 4, 5, 6 and 9 mRNAs were easily detectable in the B progenitor population, as demonstrated by strong PCR bands. Fzd1 and Fzd7 mRNA 


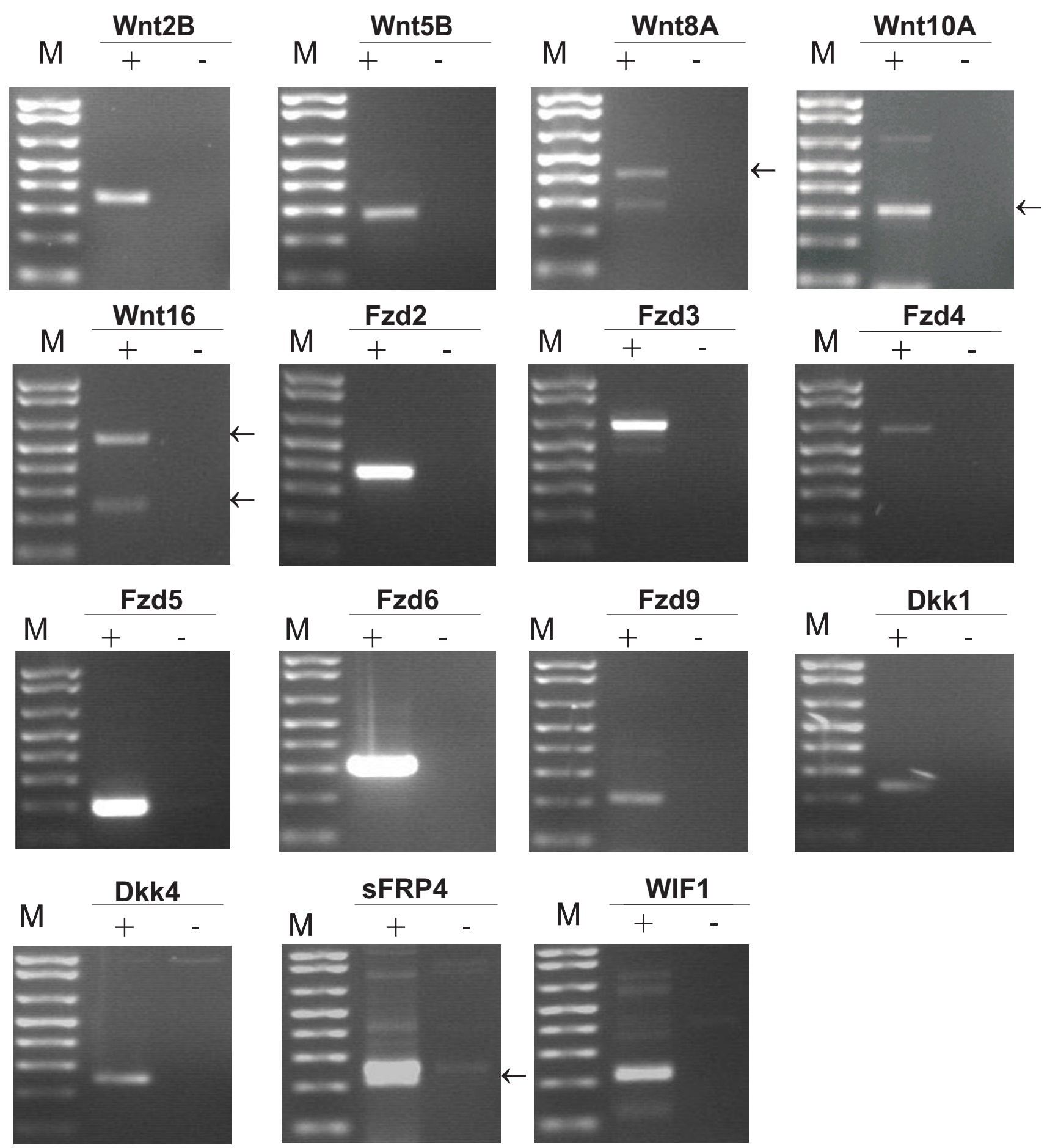

Figure I

mRNA expression analyses of Wnt ligands, Fzd receptors and Wnt antagonists. RT-PCR detection of mRNAs for Wnt ligands, Fzd receptors and Wnt antagonists in BM B progenitor cells. The + and - symbols indicate the presence and absence of reverse transcriptase in the reaction mix, respectively. One representative of two experiments is shown. Amplicon sizes: Wnt2B: 328 bp, Wnt5B:279 bp, Wnt8A: 400 bp, Wnt 10A: 296 bp, Wnt 16: 520 bp, Fzd2: 306 bp, Fzd3: 622 bp, Fzd4: 605 bp, Fzd5: 197 bp, Fzd6: 300 bp, Fzd9: 210 bp, sFRP4: 243 bp, WIFI: 200 bp, Dkkl: 235 bp, Dkk4: 24I bp. M: Size marker I kb Plus DNA ladder (Invitrogen, USA). Where two different bands are detected, an arrow marks the correct band. 
Table I: mRNA expression of Wnt ligands I-I9, Fzd receptors I-I0, Wnt antagonists sFRPI-4, WIFI, DkkI and Dkk4

\begin{tabular}{|c|c|c|c|c|c|c|c|}
\hline & $\begin{array}{c}\text { BM B } \\
\text { progenitor cells }\end{array}$ & $\begin{array}{l}\text { BM stromal } \\
\text { cells (BMS) }\end{array}$ & $\begin{array}{c}\text { Human fetal } \\
\text { brain }\end{array}$ & & $\begin{array}{l}\text { BM B progenitor } \\
\text { cells }\end{array}$ & $\begin{array}{l}\text { BM stromal cells } \\
\text { (BMS) }\end{array}$ & Human fetal brain \\
\hline Wntl & $+/-$ & - & + & FzdI & $+/-$ & - & - \\
\hline Wnt2 & - & - & + & Fzd2 & + & - & + \\
\hline Wnt2B & + & + & + & Fzd3 & + & + & + \\
\hline Wnt3 & - & - & + & Fzd4 & + & + & + \\
\hline Wnt3A & $+/-$ & - & - & Fzd5 & + & - & + \\
\hline Wnt4 & $+/-$ & - & + & Fzd6 & + & + & + \\
\hline Wnt5A & $+/-$ & + & + & Fzd7 & $+/-$ & - & + \\
\hline Wnt5B & + & + & + & Fzd8 & ND & - & ND \\
\hline Wnt6 & ND & - & ND & Fzd9 & + & - & + \\
\hline Wnt7A & - & - & + & FzdIO & - & - & - \\
\hline Wnt7B & - & - & + & Dkkl & + & + & + \\
\hline Wnt8A & + & - & + & Dkk4 & + & - & - \\
\hline Wnt8B & ND & + & ND & sFRPI & - & - & + \\
\hline Wnt9A & $+/-$ & - & + & sFRP2 & $+/-$ & + & + \\
\hline Wnt9B & $+/-$ & + & + & sFRP3 & $+/-$ & + & + \\
\hline WntIOA & + & - & - & sFRP4 & + & - & + \\
\hline WntIOB & $+/-$ & - & + & WIFI & + & ND & + \\
\hline Wntll & $+/-$ & - & + & & & & \\
\hline Wnt 16 & + & - & + & & & & \\
\hline
\end{tabular}

Genes expressed (+), not expressed (-), variably expressed between experiments(+/-), not determined (ND). N = 2. BM B progenitor cells: CDI0+IgM-CD45+ cells sorted by FACS and pooled from three different donors. Total RNA from human fetal brain was used as control.

expression was also demonstrated, but at lower levels than the other Fzds (table 1). We also detected expression of the Wnt antagonists Dkk1, Dkk4, sFRP4 and WIF1 mRNAs in the BM B progenitor cells (fig. 1 and table 1). Of these, sFRP4 mRNA was most readily detectable, suggesting the highest expression level. sFRP2 and sFRP3 mRNAs were variably detected (table 1), suggesting low expression levels.

RT-PCR performed on RNA from BM stromal cells showed expression of Wnt2B, Wnt5A, Wnt5B and Wnt8B. mRNA expression of Wnt9B was also demonstrated in these cells, although at a lower levels. Moreover, Fzd3, 4 and 6 mRNAs were detected in BM stromal cells, as well as expression of the Wnt antagonists Dkk1, sFRP2 and sFRP3 mRNAs (table 1).

\section{Regulated expression of Wnt receptors, $\beta$-catenin, plakoglobin, LEF-I and TCF-4 mRNAs during human BM B lymphopoiesis}

Identification of differential expression of Wnt signaling molecules during the $\mathrm{B}$ lymphopoiesis may reveal at which window in the process Wnt signaling is active. Thus, using quantitative real-time PCR, we examined the expression of a selection of Wnt receptors, $\beta$-catenin, plakoglobin and transcription factors in FACS sorted human BM B lineage cells representing different maturation levels; ELP cells $\left(\mathrm{CD} 10^{+} \mathrm{CD} 34^{+} \mathrm{CD} 19-\right.$, also tested to be $\left.\mathrm{CD}^{+}{ }^{+}\right)$, pro-B cells $\left(\mathrm{CD} 10^{+} \mathrm{CD} 34^{+} \mathrm{CD} 19^{+} \mathrm{CD}^{2} 0^{-} \mathrm{IgM}^{-}\right)$, large pre-B cells (CD10+CD34-CD19+CD20 dimIgM-), small pre-B (CD10+CD34-CD19+CD20-IgM-) and immature B cells (CD10+CD34-CD19+CD20+IgM+). Due to limited number of cells, expression analysis in ELP cells was restricted to seven out of ten mRNAs.

The results showed regulation of several of the important Wnt-signaling molecules, and different expression profiles were recognizable (fig. 2). mRNA levels for the plasma membrane receptors LRP5, LRP6, Fzd5 and Fzd6 dropped considerably as the cells develop from small preB cells into immature B cells. Furthermore, Fzd5 mRNA levels were strongly up-regulated as the cells commit to the B lineage (from ELP to pro-B), with a further up-regulation as the cells differentiate to pre-B cells. Fzd2 and Fzd9 mRNA levels, on the other hand, seemed to increase somewhat throughout the differentiation, with highest levels in small pre-B and immature B cells. In small pre-B cells, the mRNA levels of LRP5 and Fzd9 were about twofold higher than in the large cycling pre-B cells. The expression levels of all receptors were low compared to the expression levels of e.g. LEF- 1 and $\beta$-catenin, indicating relative low mRNA expression levels. Fzd3 and Fzd4 mRNAs were not detectable with the amount of RNA template used in these assays.

The mRNA expression of $\beta$-catenin and plakoglobin showed little variation as the cells differentiate. $\beta$-catenin mRNA was evenly expressed in ELP, pro-B, large pre-B and immature $B$, with a small increase (near two-fold) in small pre-B cells. Plakoglobin mRNA levels, in contrast, 

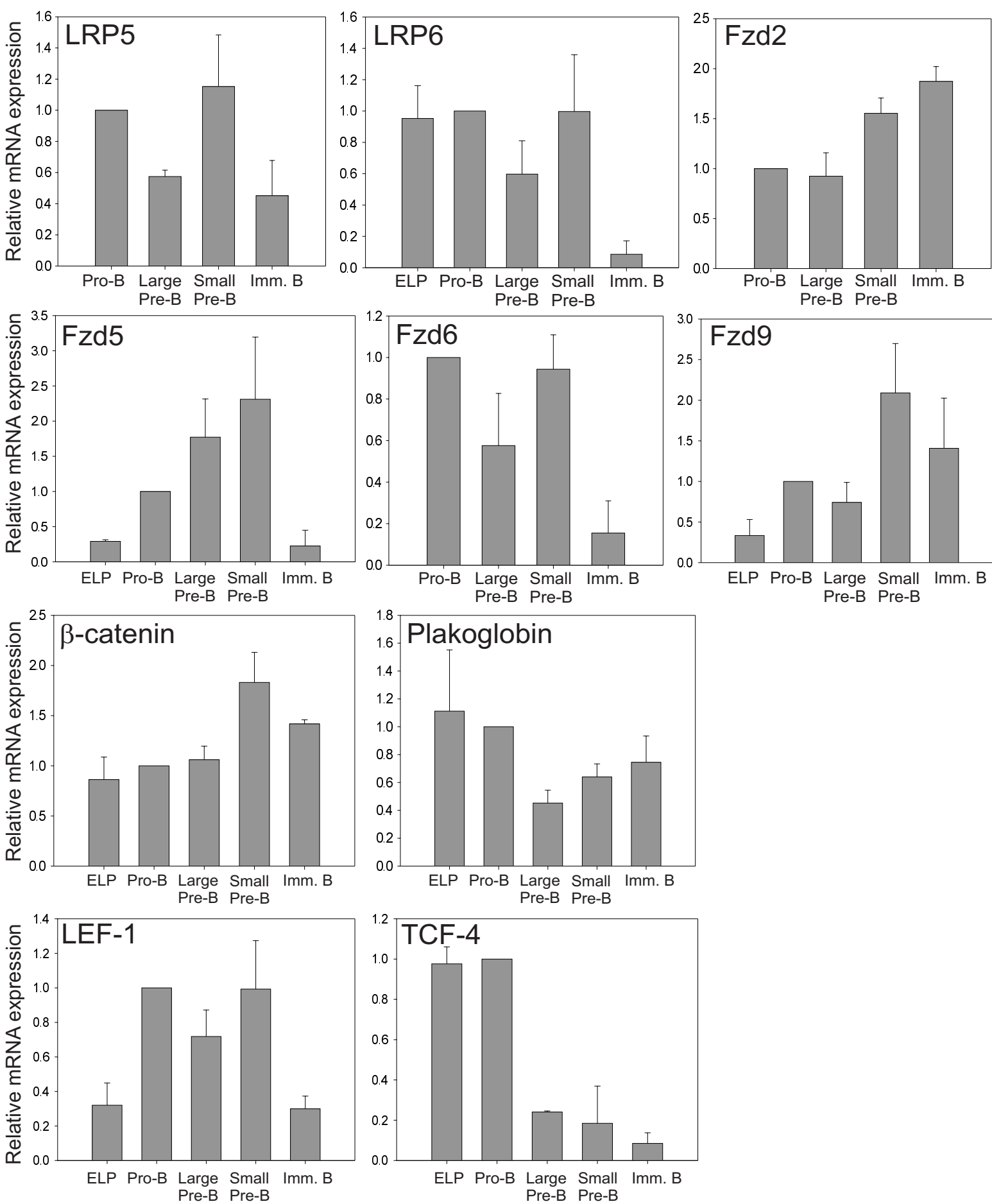

Figure 2

Real-time PCR analysis of relative mRNA expression levels of Wnt pathway molecules in BM B progenitor subpopulations. The sub-populations ELP, pro-B, large pre-B, small pre-B and immature B (imm.B) were isolated by FACS sorting. The relative mRNA expression levels of Wnt receptors and co-receptors, $\beta$-catenin, plakoglobin, LEF-I and TCF- 4 were quantified by real-time PCR analysis. Calculations of the expression levels were performed using the standard curve method and then normalized to the expression of PGKI mRNA. mRNA levels in pro-B cells were used as calibrators. The bars represent the mean of 3-5 experiments \pm SEM. 


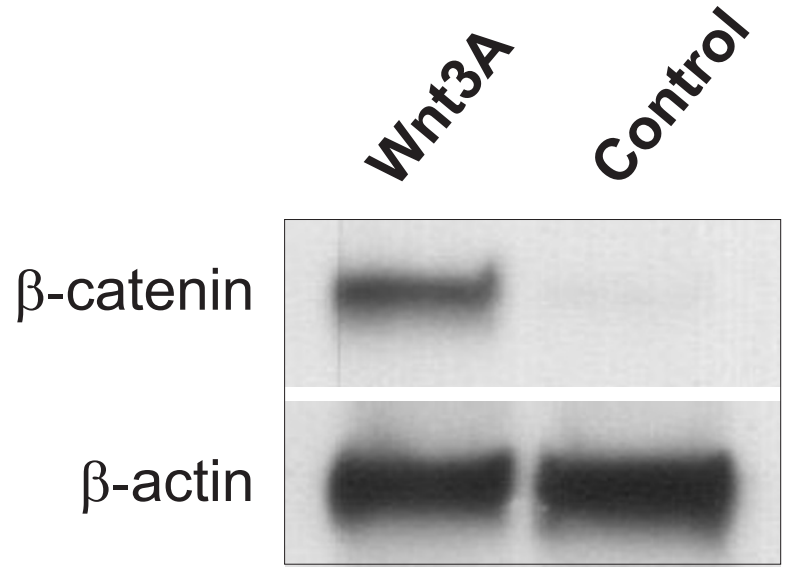

Figure 3

Wnt3A induces $\beta$-catenin stabilization in BM B progenitor cells. Western blot analysis of $\beta$-catenin levels in $\mathrm{BM} \mathrm{CD} \mathrm{I0+B}$ lineage progenitor cells stimulated with Wnt3A $(100 \mathrm{ng} / \mathrm{ml})$ or vehicle (PBS with $0.1 \%$ detoxified BSA) for 3 hours. The blots were incubated with an Ab against $\beta$-catenin, followed by an $A b$ against $\beta$-actin to ascertain equal loading in the wells. The same results were found in cells from 4 out of 5 different donors, indicating some degree of donor variation in the response to $\mathrm{Wnt} 3 \mathrm{~A}$.

decreased 2-fold as the cells became large pre-B cells (fig. 2).

LEF-1 and TCF-4 mRNA expression is highly regulated during the early B lymphopoiesis, as shown previously by microarray analysis (Hystad ME et al, manuscript in preparation and [33]). Our results showed a strong up-regulation of LEF-1 mRNA as the cells commit to the B lineage, and the expression was kept continuously high until the cells become immature $\mathrm{B}$ cells, where the level was reduced to the same as in uncommitted progenitors. Here, low LEF-1 expression was further confirmed by the absence of LEF-1 protein in B lymphocytes from peripheral blood (results not shown). The relative TCF- 4 mRNA levels, on the other hand, were high in both ELP and pro$\mathrm{B}$, and decreased (up to 5-fold) as the cells passed through Ig rearrangement (pre-B - immature B cells) (fig. 2). It should be noted that the LEF-1 mRNA expression was detected 5-8 cycles earlier than the TCF- 4 mRNA expression, indicating that LEF- 1 mRNA is much more abundant than TCF- 4 mRNA.

\section{Wnt3A induces $\beta$-catenin stabilization and accumulation in $B M B$ progenitor cells}

Our data demonstrated that human BM B progenitor cells express a set of central players in the canonical Wnt signaling pathway, potentially allowing a Wnt signal to be conveyed. To further examine whether B progenitor cells could respond to treatment with Wnt proteins, we looked for the stabilization and subsequent accumulation of the vital signaling molecule $\beta$-catenin in $\mathrm{CD} 10^{+} \mathrm{B}$ progenitor cells. When these cells were treated with Wnt $3 \mathrm{~A}$, the amount of $\beta$-catenin increased substantially compared to the very low levels in untreated cells (fig. 3). Although there were some donor variations, the results showed that the $\mathrm{B}$ progenitor cells are able to receive and communicate a signal from the Wnt pathway.

\section{Wnt3A inhibits human in vitro B lymphopoiesis}

Having identified expression of central molecules in the canonical Wnt pathway in BM B progenitor cells, we performed two variants of B lymphopoiesis assays to investigate whether Wnt signaling (using recombinant Wnt3A) had a functional effect on B lymphopoiesis in vitro. Both assays were based on coculture with the murine stromal cell line MS-5. In assay 1 hematopoietic progenitor cells (HPC) were tested for their capacity to develop into B lineage cells, whereas in assay $2 \mathrm{~B}$ progenitor cells were measured for survival and expansion. At the endpoint of the assays, each sample was subjected to quantitative flow cytometry and the total number of cells positive for the pan B cell marker CD19 was measured. In assay 2, analysis of the differentiation marker CD34 was included.

Initial analyses demonstrated that Wnt3A had an inhibitory effect when BM HPC (CD133+CD10-) were grown on stromal cells for 3 weeks at conditions that favored B lymphopoiesis (assay 1). The number of CD19+ cells in the samples treated with Wnt3A was 5 times less than the number measured in the control samples (fig. 4A). The inhibited B lymphopoiesis could result from Wnt3A suppressing differentiation of the HSC pool found in the HPC population [34], an indirect effect mediated by the stromal cells [35], or, alternatively, Wnt3A could target more committed lymphoid progenitor cells. To examine the latter possibility in more detail, we tested whether Wnt3A acted on later stages of in vitro B lymphopoiesis. BM B progenitor cells $\left(\mathrm{CD} 10^{+}\right)$were grown on stromal cells in the presence of Wnt3A or medium only for 2 weeks (assay 2). In accordance with the results from the assays using HPC, it was demonstrated on average near $50 \%$ reduction in the total number of CD19+ cells in samples treated with Wnt3A compared with control (fig. 4B). When added every third day, both sFRP1 and Dkk1 were able to counteract the effect of Wnt3A almost completely, demonstrating a specific effect of Wnt3A on in vitro B lymphopoiesis (fig. 4B). Similar results were obtained using Wnt3A protein from another source; Wnt3A conditioned medium (table 2). Moreover, the effect was independent of the source of stromal cells as the use of primary human BM stromal cells (BMS) as supportive layer did not change the outcome of the experiment (table 2). 


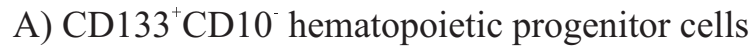

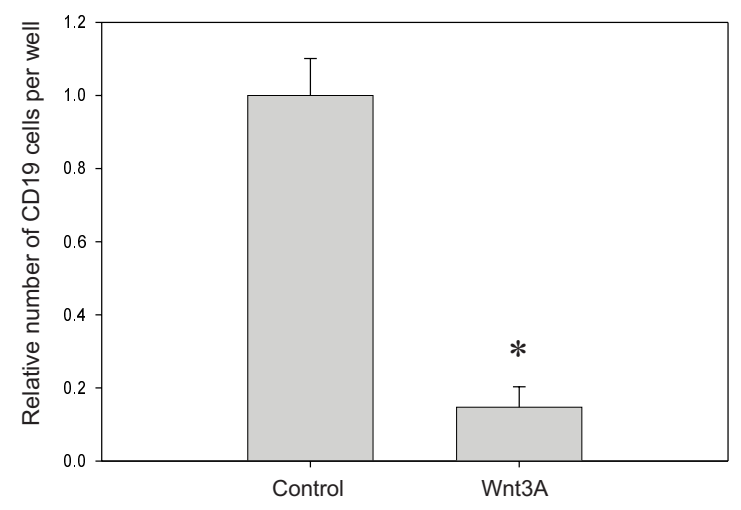

B) $\mathrm{CD} 10^{+} \mathrm{B}$ progenitor cells

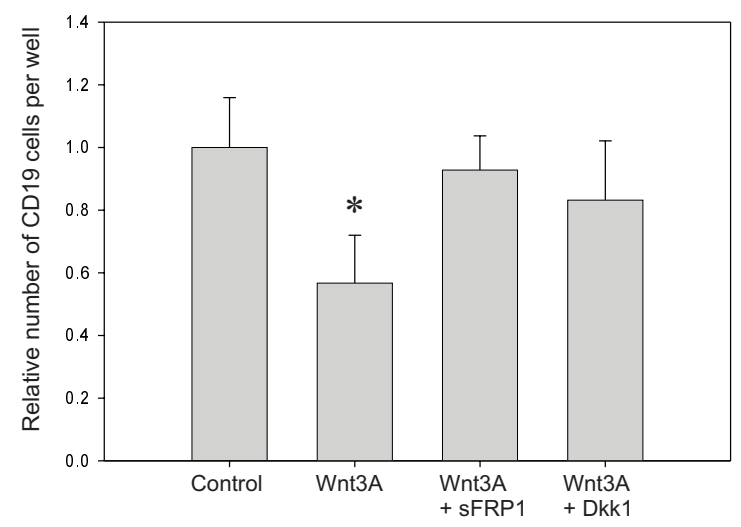

C) Percentage of $\mathrm{CD} 34^{+}$cells among the $\mathrm{CD} 19^{+}$cells

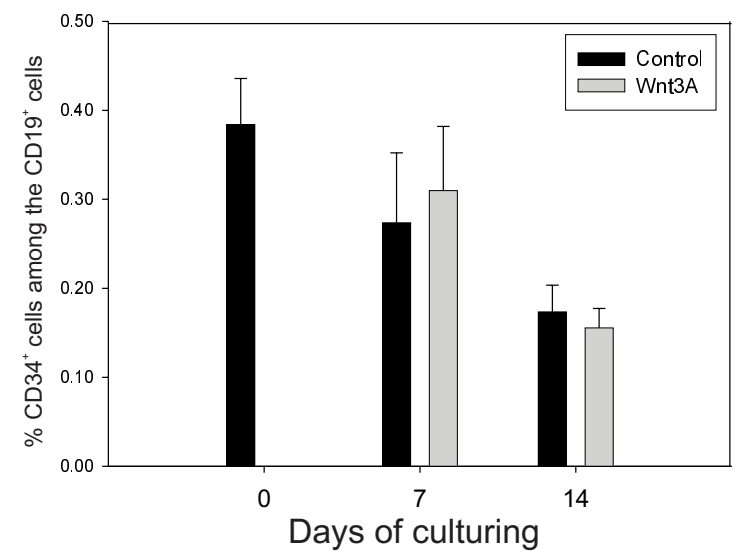

\section{Figure 4}

Wnt3A inhibits in vitro B lymphopoiesis. BM CDI33+CDI0- HPC (A: assay I) or CD I0+ B progenitor cells (B: assay 2) were cocultured with a confluent layer of the murine stromal cell line MS-5 for 3 or 2 weeks, respectively, while treated with Wnt3A (100 ng/ml), Wnt3A + sFRPI $(2 \mu \mathrm{g} / \mathrm{ml})$, Wnt3A + Dkkl $(500 \mathrm{ng} / \mathrm{ml})$ or medium only. The number of resulting CDI9+ $B$ lineage cells in each sample was determined by quantitative flow cytometry. The percentage of $C D 34^{+}$cells among the $\mathrm{CD} 19^{+}$cells were measured before and after culturing, with and without treatment with Wnt3A (C). The bars represent the mean of $\mathrm{N}$ experiments performed in duplicate, \pm SEM. A) $\mathrm{N}=6$. B) Cells treated with control medium or Wnt $3 \mathrm{~A}: \mathrm{N}=\mathrm{II}$, Wnt3A + sFRPI: $N=3, W n t 3 A+D k k I: N=2$. C) day $0: N=7$, day $7: N=3$, Day I4: $N=8 .{ }^{*} \leq 0.01$, Wilcoxon Signed Ranks Test. 
Table 2: Number of CDI 9 cells after two weeks of culturing BM CDI $0^{+}$cells on stromal cells

\begin{tabular}{clll}
\hline Exp. No. (with MS5) & Control-CM & Wnt3A-CM & Inhibition Index* \\
\hline $\mathbf{2}$ & $2182 \pm 427$ & $184 \pm 91$ & 0.08 \\
$\mathbf{3}$ & $9440 \pm 1953$ & $2652 \pm 721$ & 0.28 \\
\hline Exp. No. (with BMS) & $7292 \pm 1928$ & $2524 \pm 475$ & 0.35 \\
\hline I & Medium & rmWnt3A & Inhibition Index* \\
\hline
\end{tabular}

$\mathrm{BM} \mathrm{CDIO+}$ cells were cultured on a layer of the murine stromal cell line MS-5 in the presence of Wnt3A-conditioned medium (Wnt3A-CM) or control-conditioned medium (control-CM), or on a layer of human bone marrow stromal cells (BMS) in the presence of rmWnt3A or control medium. The numbers in the table represent the mean of duplicate wells \pm SD. *Number of CDI9+ cells in wells containing Wnt $3 A$ divided by number of cells in wells containing control-medium.

To check whether Wnt3A affected distinct early B subpopulations differently, the cells in assay 2 were additionally analyzed for expression of the CD34 differentiation marker to distinguish between pro- $\mathrm{B}$ and pre- $\mathrm{B}$ cells. The relative frequency of $\mathrm{CD} 34^{+}$cells (pro-B) decreased from $38 \%$ before culturing (day 0 ), to approximately $30 \%$ and $15 \%$ after one and two weeks of culturing, respectively. This decrease was independent of treatment with or without Wnt3A (fig. 4C). Furthermore, separation of the pre-B population into large cycling and small resting pre-B cells by surface expression of CD20 [33] revealed inhibitory effect of Wnt3A on all subpopulations (results not shown). Thus, we conclude that Wnt3A does not affect the relative proportions of different $\mathrm{BM} \mathrm{B}$ subpopulations, but has a general inhibitory effect on pro-B, pre-B and immature B cells in a stroma coculture.

\section{Wnt3A inhibits BM B progenitor cell division in vitro}

The inhibitory effect of Wnt3A on in vitro $B$ lymphopoiesis could be explained by increased apoptosis, an inhibitory effect on proliferation, or both. However, measurements of apoptosis in cells cultured without stromal cells for 1 , 2 or 3 days showed no effect of Wnt3A (results not shown), suggesting an effect on proliferation only. To verify this, we used high-resolution cell division tracking to study the initial effects of Wnt3A on B progenitor cells grown on a stromal layer. Sorted CFSE labeled CD10+ B progenitor cells were cocultured with MS-5 for 3 days in the presence of Wnt3A or medium only, and examined for the number of cell divisions by flow cytometry as well as the surface markers CD34 and CD19. The data clearly demonstrated that Wnt3A inhibited the initial divisions of $\mathrm{B}$ progenitor cells taking place in the coculture (fig. 5A). When gating for pro-B cells $\left(\mathrm{CD} 34^{+} \mathrm{CD} 19^{+}\right)$and pre- $\mathrm{B}$ cells (CD34-CD19+) separately, we found that Wnt3A inhibited proliferation of both these populations in a dose-dependent manner (fig. 5B). This effect was blocked by the Wnt antagonist sFRP1 (fig. 5B).

\section{Discussion}

Several studies have identified the canonical Wnt pathway as a regulator of the homeostasis of human and murine HSC and hematopoietic progenitor cells $[26,34,36]$. Furthermore, knockout studies (LEF-1 and Fzd9) in mice have indicated a central role for Wnt signaling in B lymphopoiesis $[24,27]$. The Wnt pathway also seems to be involved in development of leukemia [28-30]. In the present work, we wanted to study in more detail the implications of canonical Wnt signaling in human BM B lymphopoiesis. Here, we describe that a set of Wnt ligands, Fzd receptors and Wnt antagonists is expressed in BM B progenitor cells, allowing a Wnt signal to be conveyed and modulated in these cells. We demonstrate regulated expression of several Wnt receptors, $\beta$-catenin and plakoglobin as well as the transcription factors LEF-1 and TCF- 4 mRNAs during early differentiation steps in the B cell lineage, supporting the hypothesis that Wnt signaling is active in BM B lymphopoiesis. Furthermore, we show that canonical Wnt signaling, as measured by the accumulation of $\beta$-catenin levels, is induced in human BM B progenitor cells. Finally, we demonstrate that Wnt3A inhibits human stromal dependent B lymphopoiesis and that this effect is a consequence of decreased cell proliferation.

We show that $\mathrm{CD} 10^{+}$human $\mathrm{B}$ progenitor cells express a set of Wnt ligand mRNAs (2B,5B,8A, 10A and 16), of which Wnt16 is of particular interest, since this gene is activated by the E2A-Pbx1 translocation in some cases of acute lymphocytic leukaemia (ALL) [28]. However, several pre-B leukemia cell lines studied [28] do not express Wnt16, suggesting a distinct role for this factor in early B lymphopoiesis that is turned off during leukemiagenesis, except in cases where Wnt 16 is aberrantly activated by the E2A-Pbx1 fusion protein. Further, we demonstrate that primary $\mathrm{BM}$ stromal cells express mRNA of several Wnt ligands, including Wnt2B, Wnt5A, Wnt5B, Wnt8B and Wnt9B. This is partly in accordance with previous studies $[24,26]$. Taken together, these results show that both 


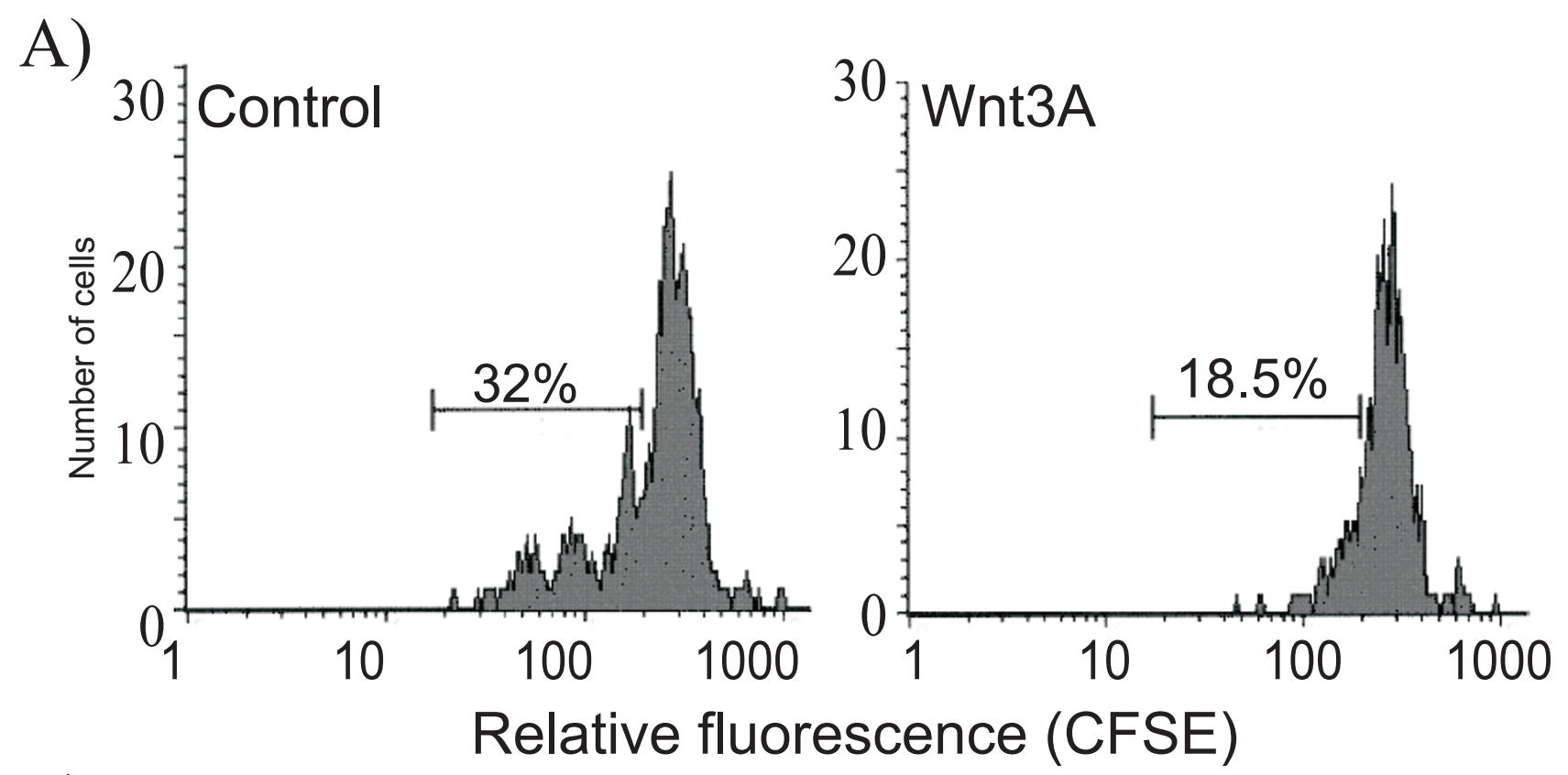

B)
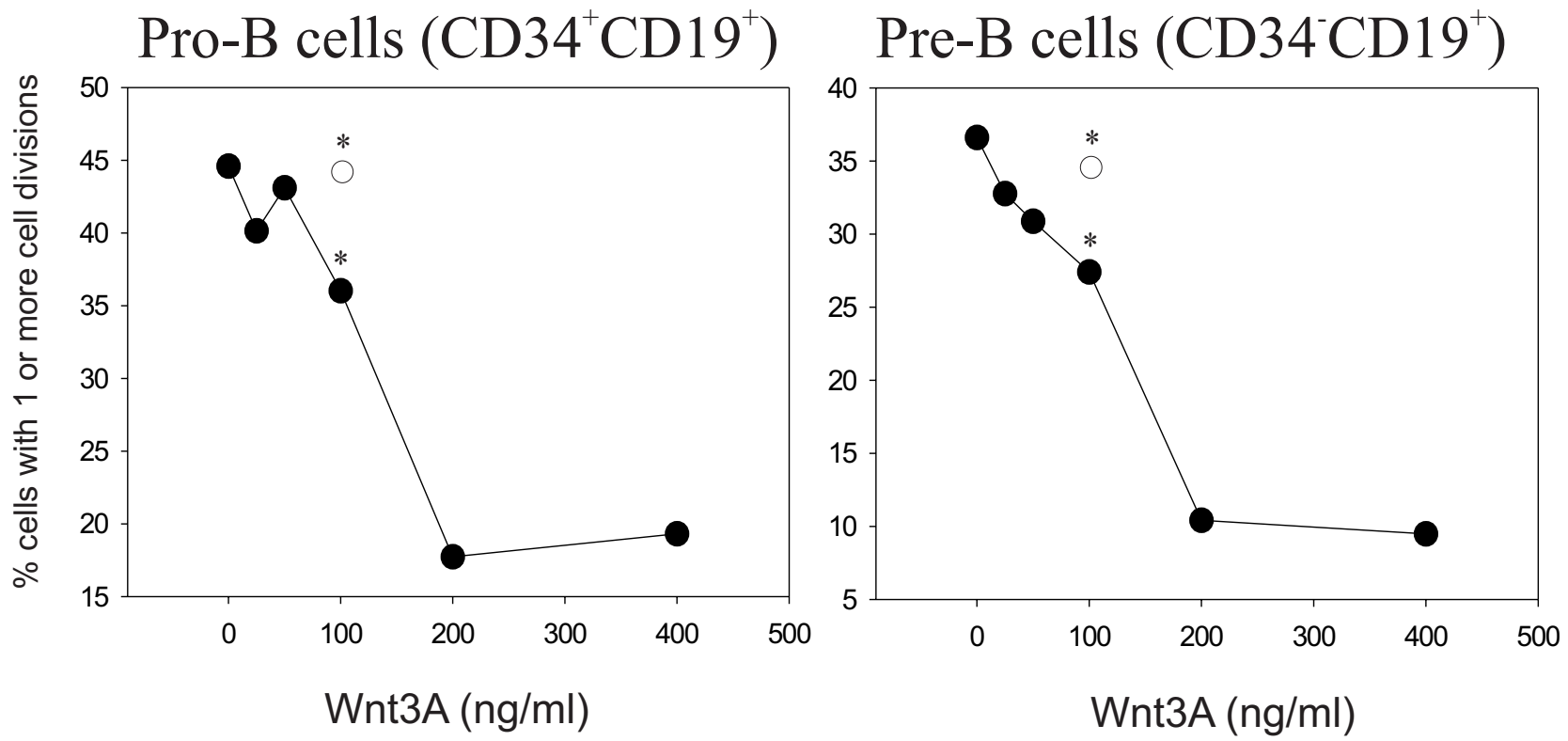

Figure 5

Wnt3A inhibits the initial phase of stromal supported cell division of BM B progenitors. Highly purified BM CDI0+CFSEmean cells were grown on a confluent layer of MS-5 and treated with Wnt $3 A$ ( $25-400 \mathrm{ng} / \mathrm{ml})$ or medium only. After three days, the cells were analyzed on a FACScan flow cytometer for the number of cell divisions of CDI9+ cells. A) Tracking histograms of cell divisions of CFSE-labeled BM B progenitor cells in the presence or absence of Wnt3A (I00 ng/ml) One representative experiment of six is shown. B) Dose dependent inhibition of cell division of CD34+ pro-B cells and CD34- ${ }^{-}{ }^{-}{ }^{-B}$ cells by Wnt3A (closed circles). The inhibitory effect of Wnt3A was blocked by Wnt antagonist sFRPI ( $2 \mu \mathrm{g} / \mathrm{ml})$ (open circle). Data are shown as percentage of cells that had gone through one or more cell divisions, as determined by cell division tracking with CFSE. One representative experiment of two is shown, except for Wnt3A (I00 ng/ml) and Wnt3A + FRPI (2 $\mu \mathrm{g} / \mathrm{ml})$ where one representative experiment of six is shown ( ${ }^{*} p<0.05$, Wilcoxon Signed Ranks Test, $\left.n=6\right)$. 
hematopoietic cells and the supporting stromal cells may produce Wnt ligands. Different Wnt ligands may have distinct effects during early B lymphopoiesis, which is a topic for future investigations.

So far, only scarce knowledge is available about both ligand specificity and tissue-restricted expression of the Fzd receptors. In our studies we found expression of a wide range of Fzd receptor mRNAs, including Fzd2, 3, 4, 5, 6 and 9, in BM B progenitor cells. Compared to the Wnt mRNAs, these are more readily detectable, indicating higher expression levels, which suggests that Wnt-signaling is important for B progenitor cells. Real-time PCR assays demonstrated differential expression of several Fzd receptor mRNAs, including Fzd5 and Fzd6, which are strongly down-regulated as the cells become immature B cells. Notably, LRP5 and LRP6 mRNAs showed a similar down-regulation. Furthermore, both Fzd5 and Fzd9 are up-regulated as the cells commit to the $\mathrm{B}$ cell lineage and go through differentiation. Interestingly, Fzd9\% mice show a depletion of developing B cells in the BM, particularly in the cycling pre-B population [27]. In contrast to this, our results show that the large cycling pre-B cells express lower levels of LRP5, LRP6, Fzd6, Fzd9, $\beta$-catenin and plakoglobin than the small resting pre-B cells. Although one should be cautious in trying to predict functional consequences from mRNA expression data, this trend suggests that Wnt signaling is not likely to be involved in a positive regulation of cycling of the large pre-B cells after Ig heavy chain rearrangement. And even though the absolute expression levels of the receptor mRNAs are low, these data suggest that during a narrow window of the development comprising pro- and pre- $\mathrm{B}$ cells, B progenitor cells might be target for Wnt signaling through these receptors.

To be able to convey a Wnt-signal, the cells have to express either of the two important molecules, $\beta$-catenin or plakoglobin. Our results show that levels of $\beta$-catenin mRNA change little during the differentiation. Although it has been demonstrated that levels of cytoplasmic $\beta$-catenin protein may vary throughout the development of thymocytes [37], these variations may not necessarily be reflected by the mRNA levels. In fact, as $\beta$-catenin is needed both for signaling purposes as well as for adhesion purposes, the mRNA levels may have to be kept relatively stable. Plakoglobin mRNA, on the other hand, decreases after the pro-B differentiation level. This corresponds to the observations made in developing murine thymocytes [37], where plakoglobin is down-regulated at the level of immature single positive thymocytes, suggesting that plakoglobin may play a central, but hitherto unexplored role in conveying a Wnt signal during lymphopoiesis. In fact, the lack of effect of knocking down $\beta$-catenin in early hematopoiesis, including B and T lymphopoiesis [38], prompted the authors to suggest that plakoglobin may stand-in for $\beta$-catenin in this respect.

The LEF-1/TCFs are directly activated by canonical Wnt signaling, and LEF-1 knockout mice show defects in pro-B cell proliferation and survival [24]. However, it cannot yet be ruled out that this effect might be a result of abolishment of the repressive functions or other non-Wnt related activities of LEF-1 [15]. Here, we have verified microarray data showing regulation of LEF- 1 and TCF- 4 during B lymphopoiesis (Hystad ME et al, manuscript in preparation and [33]). Interestingly, it has been reported that LEF-1 is a target gene for the B lymphopoiesis key transcription factor Pax-5 [39]. Moreover, LEF-1 interacts with Pax-5 and c-Myb to activate the Rag-2 promoter [40], but the accurate role of LEF-1 in B lymphopoiesis is still elusive. In contrast to LEF-1, we found TCF-4 mRNA levels to be high in ELP and pro-B cells, and lower in the more mature pre-B and immature B populations. Although expressed at lower levels, one could speculate that TCF-4 steps in for LEF-1 in the earliest lymphoid progenitors before LEF- 1 is properly switched on, potentially in conveying a Wnt signal or, alternatively, in acting as a transcription repressor of $\mathrm{B}$ lineage genes before commitment. These are topics for further studies.

Wnt antagonists play important roles in preventing or fine tuning the Wnt signal [16]. Our data show expression of the Wnt antagonists Dkk1, Dkk4, sFRP4 and WIF1 mRNAs in B progenitor cells. Dkk1, sFRP2 and sFRP3 were expressed in bone marrow stromal cells. Of these factors, Dkk1 in particular is known to be involved in a feedback loop to adjust or shut down canonical Wnt signaling [41]. It is likely that these factors are important in adjusting the incoming Wnt signals in the bone marrow microenvironment, where several cell types are able to express a wide range of ligands and Wnt receptors.

The inhibitory effect of Wnt3A on the generation and cell division of $\mathrm{B}$ progenitor cells in vitro, both with regard to pro- and pre-B cells, is in contrast to several reports on the functional effects of canonical Wnt signaling in mice. Both in murine HSC [34], developing thymocytes [25] and a wide range of cancer cells [31,42], elevated levels of $\beta$-catenin lead to increased cell proliferation. Furthermore, in fetal murine pro-B cell [24], Wnt3A conditioned medium leads to increased BrdU incorporation. Our divergent results may be due to different species, microenvironments and/or cell context. For instance, murine and human B lymphopoiesis require to a certain extent differing factor dependency [32]. However, by culturing murine BM B progenitor cells, we have not been able to demonstrate increased cell proliferation in the presence of Wnt3A (results not shown). Thus, we suspect the Wnt response to be different in fetal and adult $\mathrm{B}$ progenitor 
cells, potentially affected by the cellular microenvironment and/or context. Indeed, the fetal pro-B cells are exposed to the microenvironment of the liver and this is very different from that of the BM. For instance several regulators of the Wnt pathway are more highly expressed in fetal liver stroma than in BM stroma [43], which suggest that Wnt signaling might be regulated in a different manner and have a different role in the fetal liver than in the BM. Another important aspect that has to be taken into consideration, is that different Wnt ligands, although able to activate canonical Wnt signaling, indeed show distinct activities [44]. In addition there may also be species and location differences. However, as mentioned above, Cobas et al have demonstrated a lack of an essential role for $\beta$-catenin in BM hematopoiesis, including proliferation of B lymphocytes [38]. Thus, in contrast to findings in the fetal liver, our results may very well represent a physiological situation in the adult organism, where Wnt signaling via $\beta$-catenin is not essential for B lymphocytes, but may be used to fine tune the delicate balance between proliferation, differentiation and apoptosis taking place during early BM B lymphopoiesis.

In support of our data on an inhibitory effect of Wnt3A on cell division, it has been reported that canonical Wnt signaling hampers fibroblast cell proliferation through cell cycle blocks, potentially mediated via p53 [45]. Moreover, Wnt signaling inhibits proliferation and regulates cellcycle arrest at distinct stages of development in Drosophila wing development [46]. Thus, it is likely that the cellular context, in some cases represented by the ability of a central regulatory molecule like p53 to respond, will affect how the cells react to vital stimuli like Wnt. It has been speculated that aberrant p53 is necessary to convey the strong tumor promoting effect of abnormal Wnt signaling seen in colon cancer $[47,48]$. It is also interesting that Wnt5A has been found to inhibit B cell proliferation and can function as a tumor suppressor in hematopoietic tissue, albeit via the non-canonical $\mathrm{Wnt} / \mathrm{Ca}^{2+}$ pathway [49].

We show expression of Wnt2B, 5B, 8A, $10 \mathrm{~A}$ and 16 in $\mathrm{BM}$ CD10 $0^{+}$cells and of Wnt2B, Wnt5A, Wnt5B, Wnt8B and Wnt9B mRNAs in human primary BMS cells. Further we demonstrate that Wnt3A acts directly on B progenitor cells by increasing the levels of $\beta$-catenin, suggesting that the microenvironment may use Wnt signaling to regulate the fate of developing B lymphocytes. Yet, we cannot exclude that the functional effect of Wnt3A on in vitro B lymphopoiesis is indirect and mediated via the stromal cells, as observed for in vitro hematopoiesis [35]. The BM microenvironment is composed of a heterogeneous population of cells including fibroblasts, adipocytes, endothelial cells and osteoblasts, all derived from a common mesenchymal precursor [50]. In particular, the role of Wnt signaling in adipogenesis may be relevant here, as it has been demonstrated that Wnt10B $[51,52]$ inhibits adipogenesis, and there seems to be a positive correlation between adipogenesis and hematopoiesis [52]. This emphasizes the complexity of the interactions in the $\mathrm{B}$ lymphopoiesis maturation niche and opens for the possibility that $\mathrm{B}$ progenitor cells may manipulate the stromal support via these Wnt factors. However, it is not uncommon in developmental niches that morphogenic signals have the potential to act on several cells in the microenvironment. Therefore, it has been suggested that Wnt signaling might influence the HSCs both directly and indirectly by maintenance of the cellular elements of the stem cell niche [21]. In line with this theory, several studies have demonstrated expression of multiple Wnt mRNAs in thymocytes and the thymic microenvironment. It is likely that particular Wnts serve distinct roles, thus, cell specific effects may be achieved by "playing the Wnt repertoire" as well as through combinations with other signaling events.

\section{Conclusion}

In this study, we have demonstrated mRNA expression of several Wnt ligands, Fzd receptors and Wnt antagonists in human BM B progenitor cells and regulated expression of Fzd receptors and co-receptors, $\beta$-catenin, plakoglobin, LEF-1 and TCF- 4 mRNA in these cells during differentiation. Furthermore, we find that Wnt3A induced an accumulation of $\beta$-catenin in the BM B progenitor cells and inhibition of in vitro B lymphopoiesis. These results suggest the $\mathrm{Wnt} / \beta$-catenin pathway as a negative regulator of human stromal dependent B lymphopoiesis. This is in contrast to observations on Wnt effects in fetal murine pro-B cells, and may represent a distinction between the fetal liver and adult BM microenvironments.

\section{Methods \\ Reagents and antibodies for FACS and western blot analysis}

Recombinant murine (rm) Wnt3A, recombinant human (rh) secreted frizzled related protein 1 (sFRP1), rh Dickkopf 1 (Dkk1), rh interleukin (IL)-7, rh IL-3 and rh Flt3 ligand (FL) were purchased from R\&D Systems (Great Britain). The following monoclonal antibodies (mAbs) were used for flow cytometry: anti-CD34 PE, anti-CD10 APC, anti-CD10 PE-Cy7 and anti-CD20 APC from Becton Dickinson, Biosciences Pharmingen (San Jose, CA, USA), anti-CD19 PE-Cy5 and anti-CD34 PE-Cy5 from Immunotech (Marseille, France) and anti-CD19 PE, anti-CD45 PE and anti-IgM Fitc from Dako Cytomation (Denmark). Irrelevant isotype matched Abs were used as controls. The following Abs were used in western blot analysis: anti- $\beta$ catenin (Mouse IgG1, BD Transduction Laboratories), anti- $\beta$-actin (Goat polyclonal IgG, Santa Cruz Biotechnology), rabbit anti-mouse IgG1-HRP and rabbit anti-goat IgG-HRP (Dako cytomation, Denmark). 


\section{Primary cells and cell lines}

BM aspirates were from the iliac crest of normal adult volunteers (approved by the Regional Ethical Committee). Mononuclear cells (MNC) were separated by FicollHypaque density gradient centrifugation (Lymphoprep, Nycomed, Norway). CD10+B progenitor cells (ELP, pro-B and pre-B cells) were isolated from BM MNC using Dynabeads ${ }^{\circledR}$ M-450 Epoxy (Dynal, Oslo, Norway) directly coated with anti-CD10 mAb (clone RFAL-3, SigmaAldrich, UK) followed by detachment using CD4/CD8 DETACHaBEAD (Dynal, Norway) according to the producer 's protocol. The CD $10^{+}$cells were of 90-95\% purity, they were $\mathrm{CD} 45^{+}$and contained $4-7 \%$ IgM+ cells (immature B cells). CD34+ and CD19+ cells were isolated in a similar manner from MNC using Dynabeads ${ }^{\circledR} \mathrm{M}-450$ conjugated with anti-CD34 or anti-CD19 mAb, respectively, and CD34 or CD19 DETACHaBEAD (Dynal, Norway), respectively. $\mathrm{CD} 133^{+} \mathrm{CD} 10^{-}$cells (HPC) were isolated from the CD10-fraction of BM MNC (see above) using the MACS system (Magnetic cell sorting of human cells) and a CD133 Cell Isolation Kit (Miltenyi Biotec, Germany). Briefly, the mononuclear cells were magnetically labeled with CD133 MicroBeads and separated on a column, which was placed in the magnetic field of a MACS Separator. The magnetically labeled CD133+ cells were retained in the column while the unlabeled CD133-cells passed through. After removal of the column from the magnetic field, the magnetically retained CD133+ cells were eluted as the positively selected cell fraction. The CD133+ cells were typically of $97-98 \%$ purity. In monoculture, the cells were kept in X-VIVO $15^{\mathrm{TM}}$ (BioWhittaker, Walkersville, USA) with $0.1 \%$ detoxified BSA.

The murine stromal cell line MS-5 [53] was cultured in $\alpha$ MEM with $10 \%$ FCS and $100 \mu \mathrm{g} / \mathrm{ml}$ of penicillin and streptomycin (PAA Laboratories, Pasching, Austria) and was passaged twice a week. Cultures of human BM stromal (BMS) cells were established as previously described [54]. Briefly, total BM MNC cells depleted of CD34+ cells were seeded into $75-\mathrm{cm}^{2}$ tissue culture flasks in RPMI1640 with $10 \%$ FCS, penicillin and streptomycin. Nonadherent cells were washed off after 2 hours at $37^{\circ} \mathrm{C}$, and the adherent cells were cultured in EX-CELL 610 (JRH Biosciences, USA) with 10\% FCS, penicillin and streptomycin. The BMS cells were passaged twice before they were used for experiments.

The human ALL cell lines Reh (no ACC 22, DSMZ) and Nalm-6 (no ACC 128, DSMZ) (Hurwitz et al, 1979) were kept in X-VIVO $15^{\mathrm{TM}}$ supplemented with $100 \mu \mathrm{g} / \mathrm{ml}$ of penicillin and streptomycin.

\section{FACS analysis and cell sorting}

Cells were stained with anti-CD19 PE Ab for $30 \mathrm{~min}$ at $4{ }^{\circ} \mathrm{C}$ before analysis on FACSCalibur flow cytometer (argon-ion laser tuned at $488 \mathrm{~nm}$; Becton Dickinson). Quantitative analysis of CD19+ cells in cocultures was performed using Flow Cytometry Absolute Count Standard, from Bangs Laboratories Inc., (Fishers, IN 46038 USA). Data acquisition and analysis were performed using CELLQuest software (Becton Dickinson).

Highly purified (98-99\%) B progenitor cells for RT-PCR analysis of Wnt, Fzd and Wnt antagonist mRNA expression were obtained by sorting of $\mathrm{BM}$ CD $10^{+} \mathrm{CD} 45^{+} \mathrm{IgM}-\mathrm{B}$ progenitor cells using a FACSDiVa flow cytometer (Becton Dickinson, USA) after staining of BM CD $34^{+}$and CD19+ isolated cells with anti-CD45 PE, anti-CD10 APC and anti-IgM FITC Abs. Highly purified BM cell populations for real-time PCR were obtained by staining BM CD34+ and CD19+ cells with anti-CD10 PE-Cy7, anti-CD34 PE, anti-CD19 PE-Cy5, anti-CD22 APC and anti-IgM Fitc Abs and the following subpopulations were sorted using a FACSDiVa flow cytometer: ELP (CD10+CD34+CD19-IgM), pro-B (CD10+CD34+CD19+CD20-IgM-), large pre-B $\left(\mathrm{CD} 10^{+} \mathrm{CD} 34-\mathrm{CD} 19+\mathrm{CD} 20^{\text {dim IgM }}{ }^{-}\right)$small pre-B $\left(\mathrm{CD} 10^{+} \mathrm{CD} 34-\mathrm{CD} 19+{ }^{+} \mathrm{CD} 20-\mathrm{IgM}^{-}\right)$and immature $\mathrm{B}$ $\left(\mathrm{CD} 10^{+} \mathrm{CD} 34{ }^{-\mathrm{CD}} 19^{+} \mathrm{CD}^{20}{ }^{\text {high }} \mathrm{IgM}^{+}\right)$. Separation of large and small pre-B cells was based on both CD20 expression and size (forward scatter, FSC).

\section{PCR analysis}

Total RNA from freshly isolated and sorted BM CD $45^{+} \mathrm{CD} 10^{+} \mathrm{IgM}^{-}$cells was isolated using Absolutely RNA $^{\mathrm{TM}}$ RT-PCR Mini-prep kit (Stratagene Europe, Amsterdam, Netherland) according to the manufacturer's instructions. RNA from human fetal brain was purchased from BioChain Institute, Inc., USA. cDNA was synthesized from $1 \mu \mathrm{g}$ total RNA primed with random hexamers in a $50 \mu$ reaction using TaqMan Reverse Transcription Reagents (Applied Biosystems, Foster City, CA, USA). Control reactions lacking reverse transcriptase were always included. RT-PCR of 20 ng of total RNA was performed with a titanium polymerase (BD Biosciences, USA) in a 25 $\mu \mathrm{l}$ reaction for 37 cycles at $95^{\circ} \mathrm{C}$ for 30 seconds, $60^{\circ} \mathrm{C}$ for 30 seconds, and $68^{\circ} \mathrm{C}$ for 30 seconds. The primer sequences used to identify Wnt, Fzd and Wnt antagonist gene expression are listed in Table 3. The primer sequences was partly designed specifically for this work and partly copied from previous expression analyses [55]. For all mRNAs expressed, the amplified products have been sequenced and confirmed to represent the correct target gene.

\section{Real-time PCR}

Total RNAs from 5-20 000 freshly isolated and sorted BM $B$ progenitor cells (ELP, pro-B, large pre-B, small pre-B and immature $\mathrm{B}$ cells) were purified using Absolutely RNA ${ }^{\mathrm{TM}}$ RT-PCR Micro-prep kit (Stratagene Europe, Amsterdam, Netherland) according to the manufacturer's instructions. 
Table 3: Primer sequences used for mRNA expression analyses of Wnt ligands, Fzd receptors and Wnt antagonists

\begin{tabular}{|c|c|c|}
\hline Primer & Sequence & Amplicon (bp) \\
\hline \multirow[t]{2}{*}{ Wntl } & F-5' TAG CCT CCT CCA CGA ACC TG-3' & 239 \\
\hline & F-5' CAG CCT CGG TTG ACG ATC TTG-3' & \\
\hline \multirow[t]{2}{*}{ Wnt2 } & F-5' TGG TGG TAC ATG AGA GCT ACA GGT G-3' & 297 \\
\hline & R-5' CCC TGG TGA TGG CAA ATA CAA C-3' & \\
\hline \multirow[t]{2}{*}{ Wnt2B } & F-5' TCA TGC TCA GAA GTA GCC GAG A -3' & 328 \\
\hline & R-5' TGG CAC TTA CAC TCC AGC TTC A -3' & \\
\hline \multirow[t]{2}{*}{ Wnt3 } & F-5' CTG GCT ACC CAA TTT GGT GGT-3' & 225 \\
\hline & R-5' CAT CTA TGG TGG TGC AGT TCC A-3' & \\
\hline \multirow[t]{2}{*}{ Wnt3A } & F-5' AAG CAG GCT CTG GGC AGC TA-3' & 234 \\
\hline & R-5' GAC GGT GGT GCA GTT CCA-3' & \\
\hline \multirow[t]{2}{*}{ Wnt4 } & F-5' GAG GAG ACG TGC GAG AAA CTC AA-3' & 346 \\
\hline & R-5' ATC CTG ACC ACT GGA AGC CCT GT-3' & \\
\hline \multirow[t]{2}{*}{ Wnt5A } & F-5' ATC CTG ACC ACT GGA AGC CCT GT-3' & 358 \\
\hline & R-5' GGC TCA TGG CGT TCA CCA C-3' & \\
\hline \multirow[t]{2}{*}{ Wnt5B } & F-5' CAG CTT CTG ACA GAC GCC AAC T-3' & 279 \\
\hline & R-5' GCC TAT CTG CAT GAC TCT CCC A-3' & \\
\hline \multirow[t]{2}{*}{ Wnt6 } & F-5' GCT CCA GCC ACA GCA AGG-3' & 378 \\
\hline & R-5' CAG CCT GCC CGC CTC GTT-3' & \\
\hline \multirow[t]{2}{*}{ Wnt7A } & F-5' CCT GGG CCA CCT CTT TCT CAG-3' & 573 \\
\hline & R-5' TCC AGC TTC ATG TTC TCC TCC AG-3' & \\
\hline \multirow[t]{2}{*}{ Wnt7B } & F-5' TTT CTC TGC TTT GGC GTC CT-3' & 391 \\
\hline & R-5' TGG TTG TAG TAG CCC TGC TTC TC-3' & \\
\hline \multirow[t]{2}{*}{ Wnt8A } & F-5' TCC CAA GGC CTA TCT GAC CTA C-3' & 400 \\
\hline & R-5' CCG GCC CTG TTG TTG TGA-3' & \\
\hline \multirow[t]{2}{*}{ Wnt8B } & F-5' GCC CAG AGT GGT ATT GAA GAA TG-3' & 266 \\
\hline & R-5' TTG TCA CTG CAG CCT CCC-3' & \\
\hline \multirow[t]{2}{*}{ Wnt9A } & F-5' AAG TAC AGC AGC AAG TTC GTC AAG G-3' & 538 \\
\hline & R-5' GCA CTC CAC ATA GCA GCA CCA AC-3' & \\
\hline \multirow[t]{2}{*}{ Wnt9B } & F-5' AGT TTC AGT TCC GGC ATG AGC-3' & 340 \\
\hline & R-5' TTC ACA GCC TTG ATG CCC A-3' & \\
\hline \multirow[t]{2}{*}{ WntIOA } & F-5' ACA CAG TGT GCC TAA CAT TGC C-3' & 296 \\
\hline & R-5' AGG CCT TCA GTT TGC CCA G -3' & \\
\hline \multirow[t]{2}{*}{ WntIOB } & F-5' CCT CGC GGG TCT CCT GTT C-3' & 563 \\
\hline & R-5' GGT TAC AGC CAC CCC ATT CC-3' & \\
\hline \multirow[t]{2}{*}{ Wntll } & F-5' ACA ACC TCA GCT ACG GGC TCC T-3' & 394 \\
\hline & R-5' CCC ACC TTC TCA TTC TTC ATG C-3' & \\
\hline Wnt 16 & F-5' CTG TGC AAG AGG AAA CCG TAC CTG-3' & 520 \\
\hline & R-5' CAG CAC AGG AGC CGG AAA CT-3' & \\
\hline Fzdl & F-5' CTC TAC TTC TTC AGC ATG GCC A-3' & 230 \\
\hline & R-5' TCC ACG TTG TTA AGC CCC A-3' & \\
\hline Fzd2 & F-5' CCA TCC TAT CTC AGC TAC AAG TTT CT-3' & 306 \\
\hline & R-5' GCA GCC CTC CTT CTT GGT-3' & \\
\hline Fzd3 & F-5' TCC CCT CTG CCT GTA TGT GGT AGT-3' & 622 \\
\hline & R-5' GCT GCT CAC TTT GCT GTG GA-3' & \\
\hline Fzd4 & F-5' CTC GGC TAC AAC GTG ACC AAG AT-3' & 605 \\
\hline & R-5' AAT ATG ATG GGG CGC TCA GGG TA-3' & \\
\hline Fzd5 & F-5' GTG CCC ATT CTG AAG GAG TCA C-3' & 197 \\
\hline & R-5' TCC ATG TCG ATG AGG AAG GTG-3' & \\
\hline Fzd6 & F-5' ACT CTT GCC ACT GTG CCT TTG-3' & 300 \\
\hline & R-5' GTC GAG CTT TTG CTT TTG CCT-3' & \\
\hline Fzd7 & F-5' CAA GAC CGA GAA GCT GGA GAA G-3' & 248 \\
\hline & R-5' TGC CGA CGA TCA TGG TCA T-3' & \\
\hline Fzd8 & F-5' GGA CTA CAA CCG CAC CGA CCT-3' & 407 \\
\hline & R-5' ACC ACA GGC CGA TCC AGA AGA C-3' & \\
\hline Fzd9 & F-5' TCA AGG TCA GGC AAG TGA GCA-3' & 210 \\
\hline & R-5' AGC TTC CAG AGG AAC GCA ACA-3' & \\
\hline FzdIO & F-5' CAG GTG TGC AGC CGT AGG TTA A-3' & 212 \\
\hline & R-5' AAG CAC CAC ATC TTA GCT CCG G-3' & \\
\hline WIFI & F-5' ACG GAC CTC ACT GTG AGA AAG C-3' & 200 \\
\hline
\end{tabular}


Table 3: Primer sequences used for mRNA expression analyses of Wnt ligands, Fzd receptors and Wnt antagonists (Continued)

\begin{tabular}{|c|c|c|}
\hline & R-5' GCT GAT TTC ACA CTG CTC TCC C-3' & \\
\hline \multirow[t]{2}{*}{ sFRPI } & F-5' GGT CAT GCA GTT CTT CGG CT-3' & 206 \\
\hline & R-5' TCC TCA GTG CAA ACT CGC TG-3' & \\
\hline \multirow[t]{2}{*}{ sFRP2 } & F-5' ACC GAG GAA GCT CCA AAG GTA T -3' & 259 \\
\hline & R-5' TCA TCT CCT CAC AGG TGC ACT G -3' & \\
\hline \multirow[t]{2}{*}{ sFRP3 } & F-5' CTC ATC AAG TAC CGC CAC TCG TG-3' & 210 \\
\hline & R-5' CCG GAA ATA GGT CTT CTG TGT AGC TC-3' & \\
\hline \multirow[t]{2}{*}{ sFRP4 } & F-5' GCA CAT GCC CTG GAA CAT CAC-3' & 243 \\
\hline & R-5' ATC TTC ATG AGG GGC TCG CAG T-3' & \\
\hline \multirow[t]{2}{*}{ Dkkl } & F-5' ACC ATT GAC AAC TAC CAG CCG T -3' & 235 \\
\hline & R-5' TGG TTT CCT CAA TTT CTC CTC G -3' & \\
\hline \multirow[t]{2}{*}{ Dkk4 } & F-5' CGT TCT GTG CTA CAT GTC GTG G-3' & 241 \\
\hline & R-5' TCT TGT CCC TTC CTG CCT TGT-3' & \\
\hline
\end{tabular}

cDNAs were synthesized from total RNA primed with random hexamers using TaqMan Reverse Transcription Reagents (Applied Biosystems, Foster City, CA, USA). LEF-1 and TCF-4 (gene name TCF-7L2) mRNA expression was analyzed by real-time quantitative RT-PCR using Taqman technology according to the manufacturers procedure (Applied Biosystems). Predeveloped assay reagents including primers and probes for LRP5 (Hs00182031_m1), LRP6 (Hs00233935_m1), Fzd2 (Hs00361432_s1), Fzd5 (Hs00361869_g1), Fzd6 (Hs00171574_m1), Fzd9 (Hs00268954_s1), $\beta$-catenin (CTNNB1, Hs00170025_m1), plakoglobin (JUP, Hs00158408_m1), LEF-1 (Hs00212390_m1) and TCF-4 (Hs00181036_m1) mRNAs as well as the endogenous control phosphoglycerate kinase 1 (PGK1) (Hs99999906_m1) were supplied by Applied Biosystems and the PCR reactions were performed according to the manufacturer's instructions using Taqman Universal PCR Master Mix. Each measurement was performed in duplicate and the expression level for each gene was calculated using the standard curve method for relative quantitation of gene expression as described by the manufacturer (ABI Prism 7700 Sequence Detection System, User Bulletin 2, PE Applied Biosystems, Foster City, CA). Total RNA from the ALL cell lines Reh and Nalm6 as well as total RNA from human fetal brain were used for standard curves. Expression values for PGK1 mRNA, initially determined to be a suitable endogenous control for BM populations, were used for normalization of the expression levels. The expression level of the different genes in pro-B cells was used as a calibrator, and the expression of the other populations were calculated relative to the expression in proB cells.

\section{Western blot analysis}

The cells were treated with Wnt3A or vehicle only (PBS with $0.1 \%$ detoxified BSA) for 3 hours and total cell lysates were analyzed by Western blot using 10\% SDS polyacrylamide gels from Pierce (Rockford, USA) as described earlier [56]. The filters were pretreated with PBS containing $0.1 \%$ Tween-20 (PBS-T) and 5\% dry milk, incubated overnight with anti- $\beta$-catenin $\mathrm{Ab}$ or 1 hour with anti- $\beta$-actin Ab and then washed $2 \times 15$ min in PBS-T. The filters were then incubated with the secondary $\mathrm{Ab}$ rabbit anti-mouse IgG1-HRP Ab or rabbit anti-goat IgG-HRP Ab, respectively, for 60 minutes at room temperature and washed $2 \times 15 \mathrm{~min}$ in PBS-T before the proteins were visualized using $\mathrm{ECL}^{+}$Western Blotting Detection Reagents from Amersham Biosciences (Piscataway, NJ, USA).

\section{Hematopoietic cell-stromal cell coculture}

Assay 1: HPC (CD133+CD10-) were cultured in 24 well tissue plates (2000 cells/well) pre-seeded with MS-5 (2.5 $\times 10^{4}$ cells/well). Assay 2: B progenitor cells (CD10+) were cultured in 96 well tissue plates (8000 cells/well) preseeded with MS-5 $\left(1 \times 10^{4}\right.$ cells/well $)$. Both sets of cocultures were in $\alpha$-MEM containing $1 \%$ FCS, $100 \mu \mathrm{g} / \mathrm{ml}$ of penicillin and streptomycin, and supplemented with cytokines (for HPC: SCF, $25 \mathrm{ug} / \mathrm{ml}$ and G-CSF, 2,5 ug/ml, for B progenitor cells: IL-7, $50 \mathrm{ng} / \mathrm{ml}$, IL-3, $20 \mathrm{ng} / \mathrm{ml}$ and $\mathrm{FL}, 50 \mathrm{ng} / \mathrm{ml}$ ). In one additional experiment, the wells were pre-seeded with BMS $\left(1 \times 10^{4}\right.$ cells/well $)$ in EX-CELL 610 with $1 \%$ FCS, $100 \mu \mathrm{g} / \mathrm{ml}$ of penicillin and streptomycin and cytokines (IL-7, $50 \mathrm{ng} / \mathrm{ml}$, IL-3, $20 \mathrm{ng} / \mathrm{ml}$ and FL, $50 \mathrm{ng} / \mathrm{ml})$. Where indicated, Wnt $3 \mathrm{~A}(10-100 \mathrm{ng} / \mathrm{ml})$, Dkk1 (500 ng/ml) or sFRP1 $(2 \mu \mathrm{g} / \mathrm{ml})$ were added to the cultures. $50 \%$ of the medium was replaced weekly. After 3 (HPC) or 2 (B progenitor cells) weeks of culturing, single wells were harvested by trypsination and the $\mathrm{B}$ progenitor cells were immunophenotyped using the pan B cell marker CD19 as well as the CD34 differentiation marker and subjected to quantitative analyses (see above). Wnt3A conditioned medium and control medium were collected from L-Wnt3A cells and control nontransfected L-cells, respectively (purchased from American Type Culture Collection (ATCC), Manassas, USA), according to the manufacurer's procedure. 


\section{High-resolution cell division tracking}

BM CD34+ and CD19+ cells were labeled with 5- and 6carboxyfluorescein diacetate succinimidyl ester (CFSE; Molecular Probes, Eugene, OR, USA) as described earlier [57]. To allow unbound dye to diffuse from cells, labeled cells were seeded on a confluent layer of MS-5 and incubated for $18-24$ hours at $37^{\circ} \mathrm{C}$ in $\alpha$-MEM with $1 \%$ FCS. Subsequently, the cells were stained with CD10 APC mAb and $\mathrm{CD} 10^{+} \mathrm{CFSE}^{\text {mean }}$ cells were sorted on a BD FACSDiVa flow cytometer (Becton Dickinson). Sorted cells (1.5-2 × $10^{4}$ /well) were cultured in 48 well tissue plates pre-seeded with MS-5 ( $2 \times 10^{4}$ cells/well) supplemented with IL-7 (50 $\mathrm{ng} / \mathrm{ml})$ and FL (50 ng/ml) and treated with Wnt3A (25$400 \mathrm{ng} / \mathrm{ml}), \mathrm{Wnt} 3 \mathrm{~A}+\mathrm{sFRP} 1(2 \mu \mathrm{g} / \mathrm{ml})$ or medium only. IL-3 was left out of these cultures, because earlier experiments showed that IL-7 and FL were sufficient to support survival and proliferation of the B progenitor cells (data not shown). After three days the cells were harvested by trypsination and analyzed on a FACSCalibur flow cytometer for the number of cell divisions as well as expression of the cell surface markers CD34 and CD19.

\section{Statistical analysis}

The statistical significance of differences between groups was determined using the paired two-tailed Wilcoxon's nonparametric test, by applying SPSS 11.5 software.

\section{Abbreviations}

Wnt, Wingless-type MMTV integration site family

$\mathrm{BM}$, bone marrow

Fzd, Frizzled

HSC, hematopoietic stem cell

HPC, hematopoietic progenitor cell

CLP, common lymphoid progenitor

ELP, early lymphoid progenitor

IL-7, interleukin 7

IL-3, interleukin 3

FL, Flt3 ligand, Fms-related tyrosine kinase 3 ligand

SDF-1, stromal cell-derived factor 1

Dkk, Dickkopf

sFRP, soluble Fzd related protein

GSK3 $\beta$, glycogen synthase kinase-3 $\beta$
LRP, low density lipoprotein receptor-related protein

LEF-1, lymphoid enhancer-binding factor 1

TCF-4, transcription factor 4

WIF1, Wnt inhibitory factor 1

CFSE, carboxyfluorescein diacetate succinimidyl ester

ALL, acute lymphocytic leukaemia

CLL, chronic lymphocytic leukaemia

BSAP, B-cell lineage specific activator protein

Pax-5, paired box gene 5

Rag-2, Recombination-Activating Gene-2

Rm, recombinant murine

$\mathrm{Rh}$, recombinant human

mAb, monoclonal antibody

MNC, mononuclear cells

BMS, bone marrow stroma

BSA, bovine serum albumin

PGK1, phosphoglycerate kinase 1

\section{Authors' contributions}

GD designed and conducted experiments, oversaw research, and wrote paper. ET designed and conducted experiments, oversaw research, and wrote paper. MKN designed and conducted experiments, oversaw research. HS designed and conducted experiments. SF designed experiments, oversaw research, and wrote paper. ER designed experiments, oversaw research, and wrote paper.

\section{Acknowledgements}

We are grateful to MDs Dag Josefsen and Gunnar Kvalheim, The Norwegian Radium Hospital, for harvesting BM aspirates. We thank Mali Strand Ellefsen, Hans Christian Dalsbotten Aass and Trond Stokke at the Flow cytometry core facility for assistance in sorting the B progenitor cells. The project was partly financed with grants from the Norwegian Cancer Society and the Norwegian Research Council.

\section{References}

I. LeBien TW: Fates of human B-cell precursors. Blood 2000, 96: 9-23.

2. Bertrand FE, Eckfeldt CE, Fink JR, Lysholm AS, Pribyl JA, Shah N, LeBien TW: Microenvironmental influences on human B-cell development. Immunol Rev 2000, I75:175-186. 
3. Blom B, Spits H: Development of human lymphoid cells. Annu Rev Immunol 2006, 24:287-320.

4. Torlakovic E, Tenstad E, Funderud S, Rian E: CDI0+ stromal cells form B-lymphocyte maturation niches in the human bone marrow. J Pathol 2005, 205:3II-3I7.

5. Tokoyoda K, Egawa T, Sugiyama T, Choi BI, Nagasawa T: Cellular niches controlling B lymphocyte behavior within bone marrow during development. Immunity 2004, 20:707-718.

6. Hirose J, Kouro T, Igarashi H, Yokota T, Sakaguchi N, Kincade PW: A developing picture of lymphopoiesis in bone marrow. Immunol Rev 2002, 189:28-40.

7. Sitnicka E, Brakebusch C, Martensson IL, Svensson M, Agace WW, Sigvardsson M, Buza-Vidas N, Bryder D, Cilio CM, Ahlenius H, Maraskovsky E, Peschon JJ, Jacobsen SE: Complementary signaling through flt 3 and interleukin-7 receptor alpha is indispensable for fetal and adult B cell genesis. J Exp Med 2003, I98: I495-1506.

8. Muench MO, Humeau L, Paek B, Ohkubo T, Lanier LL, Albanese CT, Barcena A: Differential effects of interleukin-3, interleukin-7, interleukin 15, and granulocyte-macrophage colony-stimulating factor in the generation of natural killer and $B$ cells from primitive human fetal liver progenitors. Exp Hematol 2000, 28:961-973.

9. Namikawa R, Muench MO, de Vries JE, Roncarolo MG: The FLK2/ FLT3 ligand synergizes with interleukin-7 in promoting stromal-cell-independent expansion and differentiation of human fetal pro-B cells in vitro. Blood 1996, 87:188I-1890.

10. Ma Q, Jones D, Borghesani PR, Segal RA, Nagasawa T, Kishimoto T, Bronson RT, Springer TA: Impaired B-lymphopoiesis, myelopoiesis, and derailed cerebellar neuron migration in C. Proc Natl Acad Sci USA 1998, 95:9448-9453.

II. Nagasawa T, Hirota S, Tachibana K, Takakura N, Nishikawa S, Kitamura Y, Yoshida N, Kikutani H, Kishimoto T: Defects of B-cell lymphopoiesis and bone-marrow myelopoiesis in mice lacking the CXC chemokine PBSF/SDF-I. Nature 1996, 382:635-638.

12. Willert K, Brown JD, Danenberg E, Duncan AW, Weissman IL, Reya T, Yates JR III, Nusse R: Wnt proteins are lipid-modified and can act as stem cell growth factors. Nature 2003, 423:448-452.

13. Papkoff J, Schryver B: Secreted int-I protein is associated with the cell surface. Mol Cell Biol 1990, 10:2723-2730.

14. Golan T, Yaniv A, Bafico A, Liu G, Gazit A: The human Frizzled 6 (HFz6) acts as a negative regulator of the canonical Wnt. beta-catenin signaling cascade. J Biol Chem 2004, 279: | 4879-I 4888.

15. Staal FJ, Clevers HC: WNT signalling and haematopoiesis: a WNT-WNT situation. Nat Rev Immunol 2005, 5:2I-30.

16. Kawano Y, Kypta R: Secreted antagonists of the Wnt signalling pathway. J Cell Sci 2003, I I6:2627-2634.

17. Wodarz A, Nusse R: Mechanisms of Wnt signaling in development. Annu Rev Cell Dev Biol 1998, I 4:59-88.

18. Moon RT, Brown JD, Torres M: WNTs modulate cell fate and behavior during vertebrate development. Trends Genet 1997, 13:157-162.

19. Polakis P: Wnt signaling and cancer. Genes Dev 2000, 14: |837-185I.

20. Reya $\mathrm{T}$, Clevers $\mathrm{H}$ : Wnt signalling in stem cells and cancer. Nature 2005, 434:843-850.

21. Rattis FM, Voermans C, Reya T: Wnt signaling in the stem cell niche. Curr Opin Hematol 2004, I I:88-94.

22. Dravid G, Ye Z, Hammond H, Chen G, Pyle A, Donovan P, Yu X, Cheng L: Defining the Role of Wnt/ beta\}-Catenin Signaling in the Survival, Proliferation and Self-Renewal of Human Embryonic Stem Cells. Stem Cells 2005.

23. Ille $F$, Sommer $L$ : Wnt signaling: multiple functions in neural development. Cell Mol Life Sci 2005, 62: I I00-II 08.

24. Reya T, O'Riordan M, Okamura R, Devaney E, Willert K, Nusse R, Grosschedl R: Wnt signaling regulates $B$ lymphocyte proliferation through a LEF-I dependent mechanism. Immunity 2000, 13:15-24.

25. Staal FJ, Meeldijk J, Moerer P, Jay P, van de Weerdt BC, Vainio S, Nolan GP, Clevers $\mathrm{H}$ : Wnt signaling is required for thymocyte development and activates Tcf-I mediated transcription. Eur J Immunol 200 I, 3 I:285-293.

26. Van Den Berg DJ, Sharma AK, Bruno E, Hoffman R: Role of members of the Wnt gene family in human hematopoiesis. Blood 1998, 92:3189-3202.
27. Ranheim EA, Kwan HC, Reya T, Wang YK, Weissman IL, Francke U: Frizzled 9 knock-out mice have abnormal B-cell development. Blood 2005, 105:2487-2494.

28. McWhirter JR, Neuteboom ST, Wancewicz EV, Monia BP, Downing $J R$, Murre C: Oncogenic homeodomain transcription factor E2A-Pbxl activates a novel WNT gene in pre-B acute lymphoblastoid leukemia. Proc Natl Acad Sci USA 1999, 96: II $464-$ II 469 .

29. Lu D, Zhao Y, Tawatao R, Cottam HB, Sen M, Leoni LM, Kipps TJ, Corr M, Carson DA: Activation of the Wnt signaling pathway in chronic lymphocytic leukemia. Proc Natl Acad Sci USA 2004, I01:3118-3123.

30. Simon M, Grandage VL, Linch DC, Khwaja A: Constitutive activation of the Wnt/beta-catenin signalling pathway in acute myeloid leukaemia. Oncogene 2005, 24:2410-2420.

31. Derksen PW, Tjin E, Meijer HP, Klok MD, MacGillavry HD, van Oers $\mathrm{MH}$, Lokhorst HM, Bloem AC, Clevers H, Nusse R, van der NR, Spaargaren M, Pals ST: Illegitimate WNT signaling promotes proliferation of multiple myeloma cells. Proc Natl Acad Sci USA 2004, 10I:6I22-6/27.

32. Sitnicka E, Buza-Vidas N, Larsson S, Nygren JM, Liuba K, Jacobsen SE: Human CD34+ hematopoietic stem cells capable of multilineage engrafting NOD/SCID mice express flt3: distinct flt3 and c-kit expression and response patterns on mouse and candidate human hematopoietic stem cells. Blood 2003, 102: $88 \mathrm{I}-886$.

33. van Zelm MC, van der BM, de Ridder D, Barendregt BH, de Haas EF, Reinders MJ, Lankester AC, Revesz T, Staal FJ, van Dongen J]: Ig gene rearrangement steps are initiated in early human precursor $B$ cell subsets and correlate with specific transcription factor expression. J Immunol 2005, 175:59|2-5922.

34. Reya T, Duncan AW, Ailles L, Domen J, Scherer DC, Willert K, Hintz $L$, Nusse $R$, Weissman IL: A role for Wnt signalling in selfrenewal of haematopoietic stem cells. Nature 2003, 423: 409-4I4.

35. Yamane T, Kunisada T, Tsukamoto H, Yamazaki H, Niwa H, Takada S, Hayashi SI: Wnt signaling regulates hemopoiesis through stromal cells. J Immunol 200I, 167:765-772.

36. Austin TW, Solar GP, Ziegler FC, Liem L, Matthews W: A role for the Wnt gene family in hematopoiesis: expansion of multilineage progenitor cells. Blood 1997, 89:3624-3635.

37. Weerkamp F, Baert MR, Naber BA, Koster EE, de Haas EF, Atkuri KR, van Dongen JJ, Herzenberg LA, Staal FJ: Wnt signaling in the thymus is regulated by differential expression of intracellular signaling molecules. Proc Natl Acad Sci USA 2006, 103:3322-3326.

38. Cobas M, Wilson A, Ernst B, Mancini SJ, MacDonald HR, Kemler R, Radtke F: Beta-catenin is dispensable for hematopoiesis and lymphopoiesis. J Exp Med 2004, 199:22I-229.

39. Nutt SL, Morrison AM, Dorfler P, Rolink A, Busslinger M: Identification of BSAP (Pax-5) target genes in early B-cell development by loss- and gain-of-function experiments. EMBO J 1998, 17:2319-2333.

40. Jin ZX, Kishi H, Wei XC, Matsuda T, Saito S, Muraguchi A: Lymphoid enhancer-binding factor- $I$ binds and activates the recombination-activating gene-2 promoter together with cMyb and Pax-5 in immature B cells. I Immunol 2002, 169: 3783-3792.

4I. Niida A, Hiroko T, Kasai M, Furukawa $Y$, Nakamura $Y$, Suzuki $Y$, Sugano $S$, Akiyama T: DKKI, a negative regulator of Wnt signaling, is a target of the beta-catenin/TCF pathway. Oncogene 2004, 23:8520-8526.

42. Jamieson CH, Ailles LE, Dylla SJ, Muijtjens M, Jones C, Zehnder JL, Gotlib J, Li K, Manz MG, Keating A, Sawyers CL, Weissman IL: Granulocyte-macrophage progenitors as candidate leukemic stem cells in blast-crisis CML. N Engl J Med 2004, 35 I :657-667.

43. Martin MA, Bhatia M: Analysis of the human fetal liver hematopoietic microenvironment. Stem Cells Dev 2005, 14:493-504.

44. Castelo-Branco G, Wagner J, Rodriguez FJ, Kele J, Sousa K, Rawal N, Pasolli HA, Fuchs E, Kitajewski J, Arenas E: Differential regulation of midbrain dopaminergic neuron development by Wnt-I, Wnt-3a, and Wnt-5a. Proc Natl Acad Sci USA 2003, 100: 12747-12752.

45. Damalas A, Kahan S, Shtutman M, Ben Ze'ev A, Oren M: Deregulated beta-catenin induces a p53- and ARF-dependent growth arrest and cooperates with Ras in transformation. $E M B O$ J 200I, 20:4912-4922. 
46. Johnston LA, Edgar BA: Wingless and Notch regulate cell-cycle arrest in the developing Drosophila wing. Nature 1998, 394: 82-84.

47. Levina $E$, Oren M, Ben Ze'ev A: Downregulation of beta-catenin by $\mathrm{p} 53$ involves changes in the rate of beta-catenin phosphorylation and Axin dynamics. Oncogene 2004, 23:4444-4453.

48. Thorstensen L, Lind GE, Lovig T, Diep CB, Meling GI, Rognum TO, Lothe RA: Genetic and epigenetic changes of components affecting the WNT pathway in colorectal carcinomas stratified by microsatellite instability. Neoplasia 2005, 7:99-108.

49. Liang H, Chen Q, Coles AH, Anderson SJ, Pihan G, Bradley A, Gerstein $\mathrm{R}$, Jurecic $\mathrm{R}$, Jones $\mathrm{SN}$ : Wnt5a inhibits $B$ cell proliferation and functions as a tumor suppressor in hematopoietic tissue - Cancer Cell 2003, 4:349-360.

50. Pittenger MF, Mackay AM, Beck SC, Jaiswal RK, Douglas R, Mosca JD, Moorman MA, Simonetti DW, Craig S, Marshak DR: Multilineage potential of adult human mesenchymal stem cells. Science |999, 284: |43-|47.

5I. Longo KA, Wright WS, Kang S, Gerin I, Chiang SH, Lucas PC, OpP MR, MacDougald OA: Wnt I Ob inhibits development of white and brown adipose tissues. J Biol Chem 2004, 279:35503-35509.

52. Ross SE, Hemati N, Longo KA, Bennett CN, Lucas PC, Erickson RL, MacDougald OA: Inhibition of adipogenesis by Wnt signaling. Science 2000, 289:950-953.

53. Itoh K, Tezuka H, Sakoda H, Konno M, Nagata K, Uchiyama T, Uchino $\mathrm{H}$, Mori KJ: Reproducible establishment of hemopoietic supportive stromal cell lines from murine bone marrow. Exp Hematol 1989, I 7: |45-153.

54. Pribyl JAR, Shah N, Dittel BN, LeBien TW: Methods for purification and growth of human $B$ cell precursors in bone marrow stromal cell-dependent cultures. In The Immunology Methods Manual 2nd edition. Edited by: Lefkovits I. San Diego, CA: Academic; 1997:903-923.

55. Etheridge SL, Spencer G], Heath DJ, Genever PG: Expression profiling and functional analysis of wnt signaling mechanisms in mesenchymal stem cells. Stem Cells 2004, 22:849-860.

56. Myklebust JH, Smeland EB, Josefsen D, Sioud M: Protein kinase Calpha isoform is involved in erythropoietin-induced erythroid differentiation of CD34(+) progenitor cells from human bone marrow. Blood 2000, 95:510-518.

57. Bryder D, Jacobsen SE: Interleukin-3 supports expansion of long-term multilineage repopulating activity after multiple stem cell divisions in vitro. Blood 2000, 96: $1748-1755$.
Publish with Biomed Central and every scientist can read your work free of charge

"BioMed Central will be the most significant development for disseminating the results of biomedical research in our lifetime. "

Sir Paul Nurse, Cancer Research UK

Your research papers will be:

- available free of charge to the entire biomedical community

- peer reviewed and published immediately upon acceptance

- cited in PubMed and archived on PubMed Central

- yours - you keep the copyright 